dr in:. Piotr Boguś

Instytut Pojazdów Szynowych ,,TABOR”

Akademia Medyczna w Gdańsku

mgr inz. Adam Sienicki

mgr inz. Estera Wojciechowska

Instytut Pojazdów Szynowych ,TABOR”

\title{
Porównanie stanu silnika lokomotywy spalinowej ST44 przed i po remoncie przy użyciu sygnału wibroakustycznego
}

\begin{abstract}
Artykut przedstawia opis badań przeprowadzonych na silniku lokomotywy spalinowej ST44-2045 analizujacych jego stan przed i po remoncie przy wykorzystaniu sygnatów wibroakustycznych. Podano metodykę i zakres przeprowadzonych pomiarów. Dokonano opisu aparatury pomiarowej wykorzystanej do pozyskania sygnatu przyspieszenia oraz zaprezentowano wybrane wyniki analizy sygnatów wibroakustycznych, obejmujace wykorzystanie parametrów statystycznych, widm FFT, analizę nieliniowa oraz metody chwilowe z wykorzystaniem technik rozpoznawania obrazów.

Artykut powstat w wyniku realizacji projektu badawczego KBN nr 5 T12D 01125 pt. „Diagnostyka OBD silników spalinowych pojazdów szynowych przy użyciu wybranych metod przetwarzania sygnałów"
\end{abstract}

\section{Wstęp}

Silnik spalinowy, jak wszystkie urządzenia mechaniczne, podlega zużyciu i starzeniu. Istnieje więc konieczność oceny stanu technicznego silnika w każdej chwili jego życia. Typowa diagnostyka, jako narzędzie, oprócz oceny stanu technicznego ma także za zadanie zlokalizowanie źródła uszkodzenia.

Diagnostyka pojazdów szynowych ma stosunkowa krótką historię. Jej dynamiczny rozwój zaczął się dopiero w połowie lat siedemdziesiątych XX wieku, kiedy zaczęła zmniejszać się (aż do zupełnego zaniku) liczba parowozów, które zostały zastapione bardziej złożonymi lokomotywami spalinowymi i elektrycznymi. Nastapił również dynamiczny rozwój technik komputerowych sterujących prowadzonymi badaniami i pomiarami, a także oceniającymi ich wyniki.

Zaprezentowane wyniki obejmuja zastosowanie wybranych metod przetwarzania sygnałów do diagnostyki silników spalinowych pojazdów szynowych. Przeprowadzone badania polegały na porównaniu sygnału wibroakustycznego uzyskanego $\mathrm{z}$ silników lokomotyw spalinowych przed i po naprawie rewizyjnej (remoncie).

Pozyskane $\mathrm{w}$ takich warunkach sygnały wibroakustyczne zostały następnie poddane wybranym metodom analizy i przetwarzania sygnałów. Oprócz klasycznego podejścia (takiego jak np. metody Fourierowskie) w badaniach zastosowano nowoczesne metody oparte na analizie nieliniowej oraz chwilowej. Metody analizy nieliniowej bazują na teorii chaosu deterministycznego i są obecnie z powodzeniem stosowane do analizy sygnałów, $w$ tym również sygnałów wibroakustycznych, pozyskanych z silnika spalinowego $[1,3,5,9,10,13,14,15$ i 19$]$.
Metody nieliniowe, tak samo zresztą jak metody Fourierowskie, daja całościową charakterystykę sygnału,jednak nie pokazują chwilowych zmian w widmie oraz innych właściwościach sygnału. W związku $\mathrm{z}$ tym przeprowadzono również badania $\mathrm{w}$ zakresie metod chwilowych, które były już z powodzeniem stosowane do oceny wypadania zapłonu silnika spalinowego lokomotywy [4,6,7 i 8]. Zaproponowana metoda polega na analizie wybranych parametrów (w tym również parametrów nieliniowych) w przesuwającym się wzdłuż sygnału oknie czasowym. Ewolucja czasowa tych własności jest następnie reprezentowana w wielowymiarowej przestrzeni parametrów, gdzie wybrane stany silnika są wykrywane z wykorzystaniem metody grupowania danych.

\section{Aparatura pomiarowa}

Pomiary przyspieszeń na silnikach lokomotyw przed remontem wykonano za pomocą czujników przyspieszeń serii EGCS firmy Entran Devices (rys.1) o zakresie $\pm 5 \mathrm{~g}$, z których sygnał rejestrowany był za pomoca karty analogowo - cyfrowej PCL-818HD firmy ADVANTECH z częstotliwością próbkowania $\mathrm{f}_{\mathrm{Hz}}=1004,0161 \mathrm{~Hz} / \mathrm{kana}$.

Pomiary silników lokomotyw ST44 2045/2061 po naprawie wykonano również wymienionymi czujnikami EGCS oraz dodatkowo nowymi czujnikami PCB PIEZOELECTRONICS model 393B04 (rys.2), dla których sygnał wzmacniany był przenośnym 3kanałowym kondycjonerem sygnału ICP (rys.3) i dalej rejestrowany za pomocą karty analogowo - cyfrowej. 


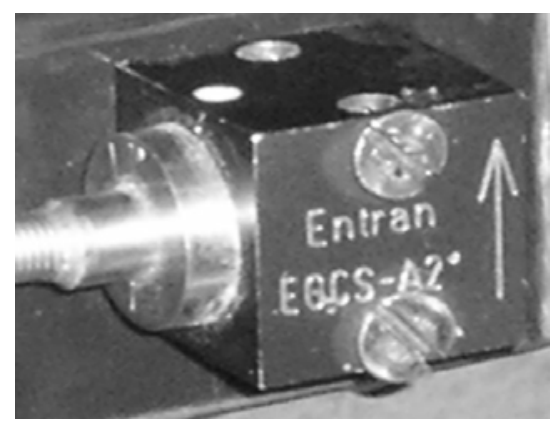

Rys. 1. Czujnik przyspieszeń firmy Entran

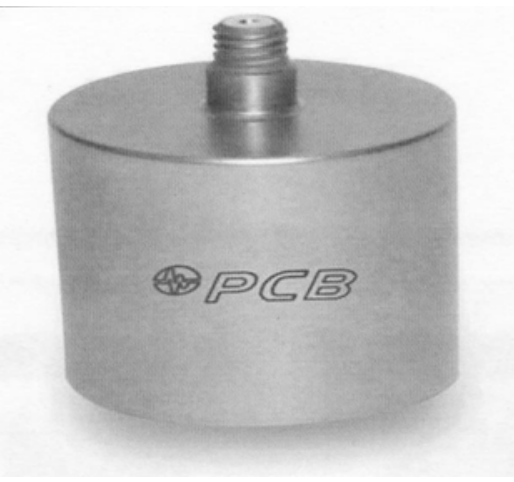

Rys. 2. Czujnik przyspieszeń PCB

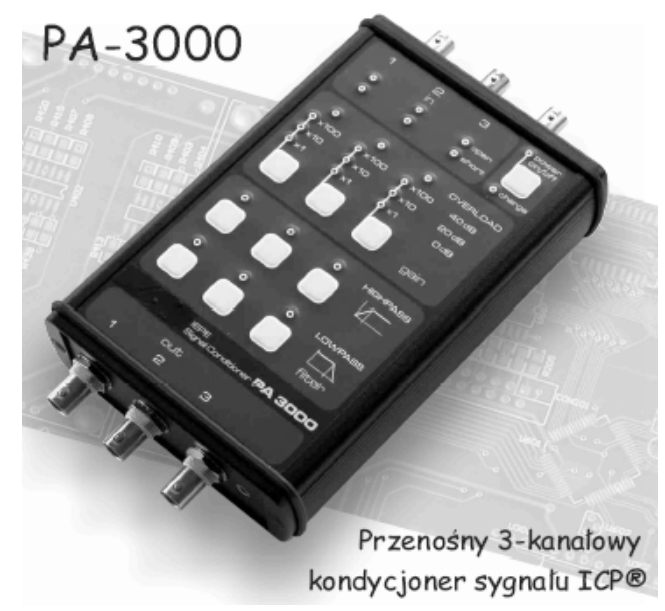

Rys. 3. Trójkanałowy kondycjoner sygnału ICP

\section{Obiekt badań - lokomotywa spalinowo- elektryczna ST 44-2045}

Rosnące przewozy towarowe spowodowały konieczność zakupienia nowoczesnych lokomotyw spalinowych dużej mocy. Umowa na dostawę takich lokomotyw została podpisana w 1965 z byłym Zwiąkiem Radzieckim. Dostawca lokomotyw była fabryka w Ługańsku. Początkowo zakupiono cztery lokomotywy, które skierowano do pracy w rejonie stacji Warszawa-Praga. Ponieważ na tamte czasy lokomotywy te okazały się bardzo dobre, złożono zamówienie na dostawę o łącznej ilości 1182 lokomotyw. Część z lokomotyw została zakupiona specjalnie do obsługi Linii Hutniczo-Siarkowej; lokomotywy te są oznaczone numerami od 2001 do 2068.
Główne parametry techniczne lokomotywy spalinowej ST44 (M62)

Tabela 1

\begin{tabular}{|c|c|c|}
\hline L.p & Nazwa parametru & $\begin{array}{l}\text { Oznaczenie i war- } \\
\text { tość parametru }\end{array}$ \\
\hline 1 & Układ osi & $\mathrm{Co} \mathrm{Co}$ \\
\hline 2 & Szerokość toru & $1435 \mathrm{~mm}$ \\
\hline 3 & Długość ze zderzakami & $17550 \mathrm{~mm}$ \\
\hline 4 & $\begin{array}{l}\text { Masa lokomotywy w } \\
\text { stanie służbowym }\end{array}$ & $116,5 \mathrm{t}$ \\
\hline 5 & $\begin{array}{l}\text { Największy nacisk } \\
\text { zestawu kołowego na } \\
\text { szyny }\end{array}$ & $190 \mathrm{kN}$ \\
\hline 6 & Prędkość maksymalna & $100 \mathrm{~km} / \mathrm{h}$ \\
\hline 7 & $\begin{array}{l}\text { Moc silnika spalinowe- } \\
\text { go }\end{array}$ & $\begin{array}{c}1470 \mathrm{~kW}(2000 \\
\mathrm{KM})\end{array}$ \\
\hline 8 & $\begin{array}{l}\text { Znamionowa prędkość } \\
\text { obrotowa silnika spali- } \\
\text { nowego }\end{array}$ & $750 \mathrm{obr} / \mathrm{min}$ \\
\hline 9 & $\begin{array}{l}\text { Prędkość obrotowa } \\
\text { biegu jałowego silnika } \\
\text { spalinowego }\end{array}$ & $400 \mathrm{obr} / \mathrm{min}$ \\
\hline 10 & $\begin{array}{l}\text { Jednostkowe zużycie } \\
\text { oleju napędowego }\end{array}$ & $215 \mathrm{~g} / \mathrm{kWh}$ \\
\hline 11 & $\begin{array}{l}\text { Pobór mocy z silnika } \\
\text { spalinowego przez } \\
\text { urządzenia pomocnicze }\end{array}$ & $193 \mathrm{~kW}(263 \mathrm{KM})$ \\
\hline 12 & $\begin{array}{l}\text { Zapas oleju napędowe- } \\
\text { go }\end{array}$ & 39001 \\
\hline 13 & Moc prądnicy głównej & $1270 \mathrm{~kW}$ \\
\hline 14 & $\begin{array}{l}\text { Moc silnika trakcyjne- } \\
\text { go(ciagła) }\end{array}$ & $190 \mathrm{~kW}$ \\
\hline
\end{tabular}


Lokomotywy pracujące na linii LHS posiadaja wózki na tor $1520 \mathrm{~mm}$. Lokomotywy te pracują w trakcji wielokrotnej, prowadząc pociagi o masie do 6000 t. Ponadto w eksploatacji znajdowała się lokomotywa ST44-1500, która posiadała prototypowe wózki o konstrukcji bezwidłowej.

Lokomotywy serii ST44 zostały skonstruowane według określonych specyficznych założeń. Jako parametry priorytetowe przyjęto prostotę budowy i obsługi, łatwość uruchamiania w każdych warunkach eksploatacji i dużą siłę pociagową. Lokomotywy stanowiły zunifikowany spalinowy pojazd trakcyjny dla kolei we wszystkich krajach byłego RWPG. Takie założenia potwierdziły się $\mathrm{w}$ praktyce i miały swoje zalety w okresie intensywnego ruchu towarowego na PKP. Lokomotywa ST44 okazała się niezastapioną $\mathrm{w}$ ciężkich warunkach zimowych. Brak jakichkolwiek zabezpieczeń ze strony prądnicy głównej i silników trakcyjnych spowodował, że lokomotywy te bez problemów radziły sobie $\mathrm{z}$ najcięższymi pociagami poruszającymi się po sieci PKP.

Niestety tego rodzaju konstrukcja ma również poważne wady, które w obecnych warunkach właściwie dyskwalifikują te pojazdy. Do wad lokomotywy ST44 należą:

- prymitywny dwusuwowy silnik spalinowy, zaadaptowany bez większych zmian z lekkich jednostek morskich $\mathrm{i}$ nie odbiegające od innych lokomotyw deklarowane zużycie paliwa, które w praktyce okazało się znacznie większe przy niewielkich obciążeniach lokomotywy

- niewielki w odniesieniu do zużycia zbiornik paliwa, co w odczuwalny sposób zmniejsza zasięg lokomotywy (był to poważny problem w pierwszych latach eksploatacji na LHS)

- znaczna emisja toksycznych spalin i duża emisja hałasu

- uszkodzenia uszczelnień układu chłodzenia silnika spalinowego

- mało elastyczne zawieszenie, powodujące podwyższone zużycie torów podczas jazdy.

$\mathrm{Na}$ PKP lokomotywy te są systematycznie wycofywane $\mathrm{z}$ eksploatacji tam, gdzie nie jest wymagane ich użycie. $Z$ ilości 1182 lokomotyw pozostało obecnie około 250 sztuk. W niektórych krajach jak Niemcy i Węgry lokomotywy te zostały zmodernizowane. Uzyskały nowy silnik spalinowy amerykańskiej firmy Caterpilar, sterowanie mikroprocesorowe oraz nowa kabinę maszynisty. PKP nie przewidują modernizacji tych lokomotyw, poza taborem pracującym na szerokotorowej linii LHS. Lokomotywy te cieszą się natomiast dużym zaufaniem u prywatnych przewoźników i z chęcią są przez nich kupowane [16].

\section{Pomiary przyspieszeń na silniku lokomoty- wy ST44-2045 przed i po naprawie rewi- zyjnej}

\subsection{Badania lokomotywy ST44-2045 przed remon- tem, październik 2005}

Pomiary przyspieszeń na silniku lokomotywy ST44-2045 przed i po naprawie rewizyjnej wykonano w stacji diagnostycznej w Zamościu. Obiektem badań był silnik spalinowy typu 14D40 nr 8849. Zgodnie z książką pokładową lokomotywy, jej przebieg przed remontem (stan na 27.10.2005) wynosił $575917 \mathrm{~km}$.

Pomiary wykonywane były pod obciążeniem (na oporniku wodnym) dla odpowiednio dostosowanych mocy w wyznaczonych punktach pomiarowych. W trakcie badań wykonano pomiary w 7 punktach roz-

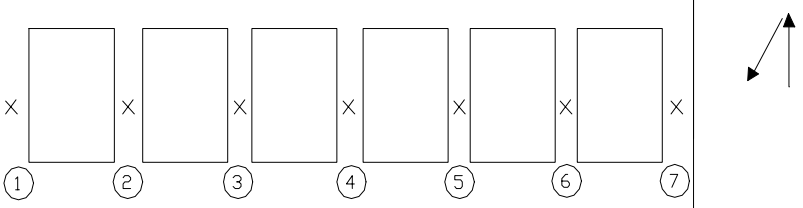

Rys. 5. Rozmieszczenie punktów pomiarowych

Czujniki mocowano na korpusie silnika w miejscach odpowiadających łożyskowaniu wału korbowego silnika (rys.6a). Każdy punkt pomiarowy rejestrował przyspieszenia w dwóch kierunkach: pionowym oraz poziomym poprzecznym (rys.6b). Dla każdego wyznaczonego punktu wykonano dwie serie pomiarowe.

Ze względu na dysponowanie ograniczoną liczbą czujników pomiarowych jednorazowo wykonywano pomiary w trzech punktach pomiarowych. Oznacza to, iż na każdej lokomotywie wykonano 3 serie pomiarów powtarzając je 2-krotnie. Wartości mocy i prędkości obrotowych odpowiadające nastawom wziętym do analizy przedstawiono w tabelach 2, 3 i 4 .

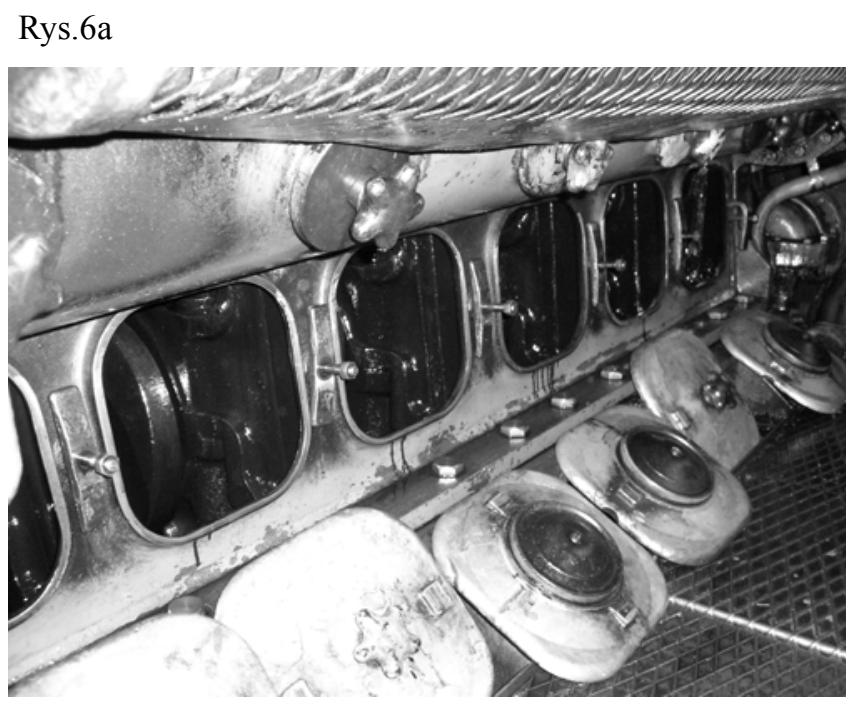


Rys.6b

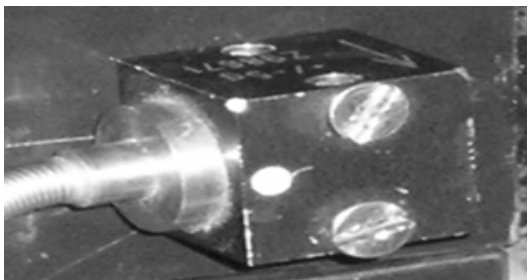

Rys. 6. Miejsca łożyskowania wału korbowego (6a) oraz czujniki umiejscowione w punkcie pomiarowym (6b)

Nastawy (moc i prędkość obrotowa) dla lokomotywy ST44-2045 przed remontem (punkty 1,2,3 próba 1 i 2)

Tabela 2

\begin{tabular}{|c|c|c|c|c|c|}
\hline \multicolumn{3}{|c|}{ Próba 1 } & \multicolumn{3}{c|}{ Próba 2 } \\
\hline Nastawa & $\begin{array}{c}\text { Moc } \\
{[\mathrm{kW}]}\end{array}$ & $\begin{array}{c}\text { Prędkość } \\
\text { obrotowa } \\
\text { wału kor- } \\
\text { bowego } \\
{[\mathrm{obr} / \mathrm{min}]}\end{array}$ & Nastawa & $\begin{array}{c}\text { Moc } \\
{[\mathrm{kW}]}\end{array}$ & $\begin{array}{c}\text { Prędkość } \\
\text { obrotowa } \\
\text { wału kor- } \\
\text { bowego } \\
{[\mathrm{obr} / \mathrm{min}]}\end{array}$ \\
\hline 2 & 244 & 409 & 2 & 234 & 409 \\
\hline 15 & 903 & 701 & 15 & 909 & 703 \\
\hline
\end{tabular}

Nastawy (moc i prędkość obrotowa) dla lokomotywy ST44-2045 przed remontem (punkty 4,5,6 próba 1 i 2)

Tabela 3

\begin{tabular}{|c|c|c|c|c|c|}
\hline \multicolumn{3}{|c|}{ Próba 1 } & \multicolumn{3}{c|}{ Próba 2 } \\
\hline Nastawa & $\begin{array}{c}\text { Moc } \\
{[\mathrm{kW}]}\end{array}$ & $\begin{array}{c}\text { Prędkość } \\
\text { obrotowa } \\
\text { wału } \\
\text { korbowego } \\
{[\mathrm{obr} / \mathrm{min}]}\end{array}$ & Nastawa & $\begin{array}{c}\text { Moc } \\
{[\mathrm{kW}]}\end{array}$ & $\begin{array}{c}\text { Prędkość } \\
\text { obrotowa } \\
\text { wału } \\
\text { korbowego } \\
{[\mathrm{obr} / \mathrm{min}]}\end{array}$ \\
\hline 2 & 344 & 406 & 2 & 309 & 412 \\
\hline 15 & 1174 & 735 & 15 & 993 & 750 \\
\hline
\end{tabular}

Nastawy (moc i prędkość obrotowa) dla lokomotywy ST44-2045 przed remontem (punkty 5,6,7 próba 1 i 2)

Tabela 4

\begin{tabular}{|c|c|c|c|c|c|}
\hline \multicolumn{3}{|c|}{ Próba 1 } & \multicolumn{3}{c|}{ Próba 2 } \\
\hline Nastawa & $\begin{array}{c}\text { Moc } \\
{[\mathrm{kW}]}\end{array}$ & $\begin{array}{c}\text { Prędkość } \\
\text { obrotowa } \\
\text { wału } \\
\text { korbowego } \\
{[\mathrm{obr} / \mathrm{min}]}\end{array}$ & Nastawa & $\begin{array}{c}\text { Moc } \\
{[\mathrm{kW}]}\end{array}$ & $\begin{array}{c}\text { Prędkość } \\
\text { obrotowa } \\
\text { wału } \\
\text { korbowego } \\
{[\mathrm{obr} / \mathrm{min}]}\end{array}$ \\
\hline 2 & 251 & 415 & 2 & 260 & 409 \\
\hline 15 & 983 & 752 & 15 & 1030 & 755 \\
\hline
\end{tabular}

\subsection{Badania lokomotywy ST44 po remoncie}

Na przełomie roku 2005/2006 lokomotywa ST442045 (rys. 4) przeszła naprawę rewizyjną o zakresie prac, obejmującym przegląd podzespołów i zespołów połączony z częściowym ich demontażem z pojazdu trakcyjnego oraz naprawę lub wymianę elementów zużytych bądź uszkodzonych, zgodnie z [11]. Przebieg lokomotywy po naprawie (stan na 31.03.2006) wynosił $131 \mathrm{~km}$.

Obiektem badań był ten sam silnik spalinowy typu 14D40 nr 8849 (ST44-2045) po remoncie. Pomiary wykonywane były pod obciążeniem (na oporniku wodnym) dla odpowiednio dostosowanych mocy w wyznaczonych punktach pomiarowych.

W trakcie badań wykonano pomiary w 6 punktach (rys. 7 i 8). Czujniki mocowano na korpusie silnika w miejscach odpowiadających łożyskowaniu wału korbowego silnika. Każdy punkt pomiarowy rejestrował przyspieszenia w dwóch kierunkach: pionowym (czujniki Entran) oraz poziomym poprzecznym (czujniki PCB). Dla każdego wyznaczonego punktu wykonano dwie serie pomiarowe. Wartości mocy i prędkości obrotowych, odpowiadające nastawom wziętym do analizy, przedstawiono $\mathrm{w}$ tabeli 5

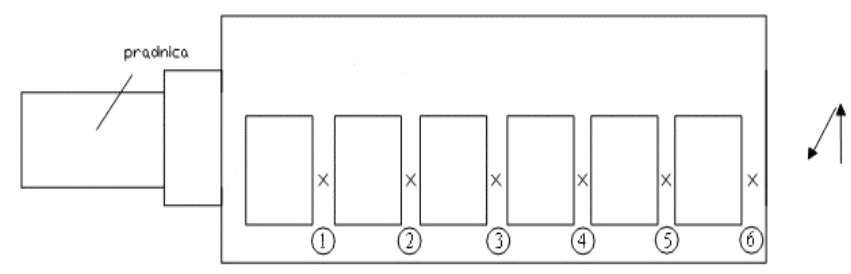

Rys. 7. Rozmieszczenie punktów pomiarowych

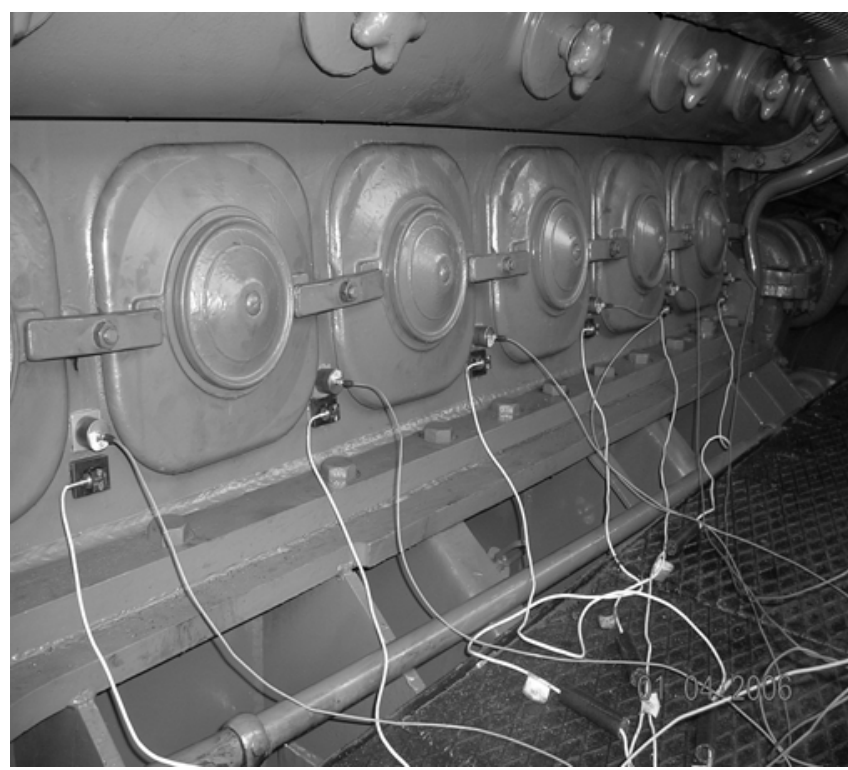

Rys. 8. Czujniki zamontowane w punktach pomiarowych $1,2,3,4,5$ i 6 
Nastawy (moc i prędkość obrotowa) dla lokomotywy ST44 - 2045 po remoncie (punkty 1, 2, 3, 4, 5 i 6)

Tabela 5

\begin{tabular}{|c|c|c|c|c|c|}
\hline \multicolumn{3}{|c|}{ Próba 1} & \multicolumn{3}{|c|}{ Próba 2} \\
\hline Nastawa & $\begin{array}{l}\mathrm{Moc} \\
{[\mathrm{kW}]}\end{array}$ & $\begin{array}{l}\text { Prędkość } \\
\text { obrotowa } \\
\text { wału kor- } \\
\text { bowego } \\
\text { [obr/min] }\end{array}$ & Nastawa & $\begin{array}{l}\text { Moc } \\
{[\mathrm{kW}]}\end{array}$ & $\begin{array}{c}\text { Prędkość } \\
\text { obrotowa } \\
\text { wału kor- } \\
\text { bowego } \\
\text { [obr/min] }\end{array}$ \\
\hline 2 & 270 & $412 \div 438$ & 2 & $250 \div 270$ & $412 \div 438$ \\
\hline 15 & 1230 & $745 \div 759$ & 15 & $1201 \div 1263$ & $745 \div 759$ \\
\hline
\end{tabular}

Podane w tabeli 5 zakresy prędkości obrotowych oraz mocy wynikaja z tego, że na stanowisku badawczym silnik był sterowany sterownikiem lokomotywy, który wykorzystuje charakterystykę UIC optymalnego sterowania mocą silnika $\mathrm{w}$ funkcji jego obrotów $\mathrm{P}_{\mathrm{UIC}}$ $=\mathrm{f}\left(\mathrm{n}_{\text {wału }}\right)$. Obroty wału od $\div$ do [obr/min] odpowiadaja zapisowi mocy od $\div$ do $[\mathrm{kW}]$, bo wynikają z wykresu UIC a układ sterowania silnika nie potrafi zrealizować ustalonych stałych obrotów.

Naprawa obejmowała między innymi:

- oczyszczenie kadłuba i głowicy silnika, dokonanie próby szczelności kanałów oraz przestrzeni wodnych, sprawdzenie bloku cylindrowego, tulei cylindrowych i prowadnic popychaczy zaworów

- sprawdzenie korbowodu, tłoków, sworzni i pierścieni tłokowych, łożysk i śrub

- sprawdzenie tłumika, koła zamachowego, wałów rozrządu i łożysk, kół zębatych, popychaczy zaworów i pomp wtryskowych

- skorygowanie linii wału korbowego

- oczyszczenie i naprawę thumika spalin, kolektorów ssących, wydechowych oraz kompensatorów

- oczyszczenie i sprawdzenie turbosprężarki, doładowarki i chłodnicy powietrza doładowania

- dokonanie prób silnika spalinowego na stanowisku w hamowni.

\section{Zastosowane metody analizy sygnałów}

Sygnały wibroakustyczne uzyskane z silnika spalinowego zostały poddane następującym metodom analizy sygnałów:

- analiza widma FFT [17 i 18]

- obliczenie globalnych parametrów statystycznych takich jak wartość średnia, mediana i średni błąd kwadratowy [15,17 i 18]

- analiza nieliniowa [1 i 9]

- analiza krótkoczasowa [17 i 18].

Analiza nieliniowa jest metodą bazującą na teorii chaosu deterministycznego. W metodzie tej zakłada się, że dany jest pewien, poddany próbkowaniu, sygnał czasowy $\mathrm{x}(\mathrm{t})$. Zasadniczą jej ideą jest założenie, że przestrzeń w której należy oglądać dynamiczną strukturę sygnału nie jest jednowymiarową przestrzenią możliwych wartości $\mathrm{x}(\mathrm{t})$, ale że ewolucja dynamiczna zachodzi w przestrzeni wektorów $\mathbf{w}(\mathrm{t})$ wyższego wymiaru [1,3,5 i 9]. Przestrzeń tę odtwarza się poprzez tzw. zanurzenie szeregu czasowego na bazie wybranego opóźnienia czasowego (ang. time-delay embedding). W praktyce dąży się do odtworzenia przestrzeni, która jest formalnie równoważna oryginalnej przestrzeni fazowej układu. W tym celu używa się współrzędnych utworzonych $\mathrm{z}$ obserwowanych zmiennych oraz ich opóźnień. Wybiera się okres czasu $\tau$, po czym oblicza wartości sygnału po czasie $\tau$, czyli bierze się pod uwagę kolejne wielkości

$\mathrm{x}_{\mathrm{i}}=\mathrm{x}\left(\mathrm{t}_{\mathrm{i}}\right), \mathrm{x}_{\mathrm{i}+1}=\mathrm{x}\left(\mathrm{t}_{\mathrm{i}}+\tau\right), \mathrm{x}_{\mathrm{i}+2}=\mathrm{x}\left(\mathrm{t}_{\mathrm{i}}+2 \tau\right), \ldots \ldots$

Dla odtworzenia ewolucji w n-wymiarowej przestrzeni stanu konstruuje się odpowiednie n-wymiarowe wektory $\mathbf{w}$ utworzone $\mathrm{z}$ kolejno wybieranych n-elementowych ciągów

$$
\begin{gathered}
\mathbf{w}_{1}=\left(\mathrm{x}_{1}, \mathrm{x}_{2}, \ldots ., \mathrm{x}_{\mathrm{n}}\right), \\
\mathbf{w}_{2}=\left(\mathrm{x}_{2}, \mathrm{x}_{3}, \ldots ., \mathrm{x}_{\mathrm{n}+1}\right), \\
\mathbf{w}_{3}=\left(\mathrm{x}_{3}, \mathrm{x}_{4}, \ldots ., \mathrm{x}_{\mathrm{n}+2}\right), \\
\mathbf{w}_{\mathrm{i}}=\left(\mathrm{x}_{\mathrm{i}}, \mathrm{x}_{\mathrm{i}+1}, \ldots . ., \mathrm{x}_{\mathrm{i}+\mathrm{n}-1}\right)
\end{gathered}
$$

Są to tzw. wektory opóźnienia czasowego. Kolejne wektory $\mathbf{w}_{1}, \mathbf{w}_{2}, \mathbf{w}_{3}, \ldots .$. wyznaczają ewolucję w nwymiarowej przestrzeni stanu. Charakterystyczne opóźnienie czasowe $\tau$ znajduje się jako pierwsze miejsce zerowe funkcji autokorelacji sygnału albo jako pierwsze minimum uśrednionej informacji wzajemnej (ang. average mutual information). Mając dane $\tau$ można oszacować właściwy wymiar przestrzeni fazowej d, w której odtwarza się dynamika systemu. Stosuje się wówczas metodę najbliższych fałszywych sąsiadów (ang. nearest neighbour method). Gdy dane jest $\tau$ i d można odtworzyć dynamikę systemu i dokonać analizy jakościowej zachowania się układu w przestrzeni fazowej. Można również obliczyć wartości szeregu nieliniowych parametrów takich jak np. wykładniki Lapunowa lub wymiary fraktalne. Parametry te mogą stać się podstawą do diagnostyki badanych systemów dynamicznych, w najprostszym przypadku poprzez ich porównanie dla zachowań prawidłowych i nieprawidłowych.

Zastosowana analiza krótkoczasowa bazuje na obliczeniu wybranych parametrów w oknie przesuwającym się w czasie wzdłuż sygnału, a następnie na obserwacji położenia i ewolucji dynamicznej wektorów stanu $\mathrm{w}$ wielowymiarowej przestrzeni parametrów [4,6,7 i 8]. Ogólny schemat chwilowej analizy sygnałów jest następujący:

1. wybór wielkości okna czasowego, 
2. w przesuwającym się oknie czasowym oblicza się wybrane parametry (np. prążki FFT, parametry statystyczne itp.),

3. dla danego położenia okna wartości parametrów reprezentują punkt $\mathrm{w}$ wielowymiarowej przestrzeni parametrów (tyle wymiarów przestrzeni ile parametrów),

4. jeśli rozważyć okno przesuwające się w czasie wzdłuż sygnału, to wartości parametrów dla kolejnych położeń reprezentują kolejne punkty w przestrzeni parametrów,

5. dla danego skończonego sygnału w wyniku przesunięcia okna wzdłuż całego sygnału otrzymuje się zbiór punktów w wielowymiarowej przestrzeni parametrów,

6. dla porównania różnych sygnałów dokonuje się grupowania danych w przestrzeni parametrów i porównuje się środki uzyskanych grup.

Grupowanie danych jest jedną z podstawowych technik rozpoznawania obrazów i polega na podziale zbioru danych na grupy elementów najbardziej do siebie podobnych. Zazwyczaj podczas grupowania zakłada się z góry określoną liczbę grup i próbuje się podzielić zbiór danych na tę założoną liczbę grup. Algorytm grupowania danych należy do tzw. ,metod nauczania bez nadzoru", bowiem automatycznie przeprowadza grupowanie zbioru danych na grupy elementów najbardziej do siebie podobnych. W pracy zastosowano klasyczny algorytm grupowania po c średnich (ang. c-means algorithm of clustering) [2 i 12].

\section{Rezultaty badawcze}

Analizę zarejestrowanych sygnałów zrealizowano z wykorzystaniem oprogramowania NDT (Nonlinear Dynamics Toolbox) oraz z programu MATLAB. W MATLABIE wykorzystano zarówno gotowy toolbox, realizujący analizę nieliniową TSTOOL jak i własne oprogramowanie ASC do analizy nieliniowej. Program ASC (Analiza Szeregów Czasowych) został napisany przez autorów.

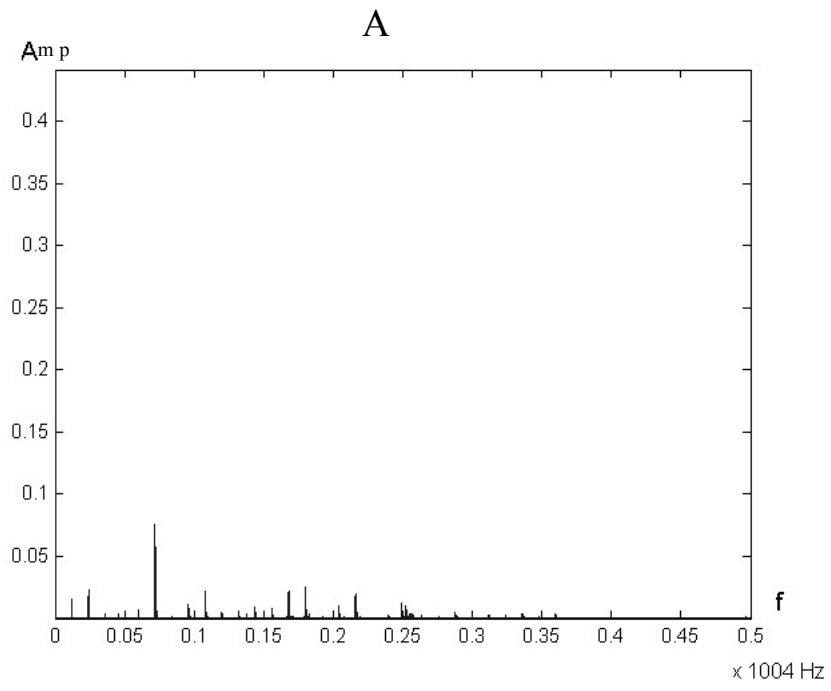

B

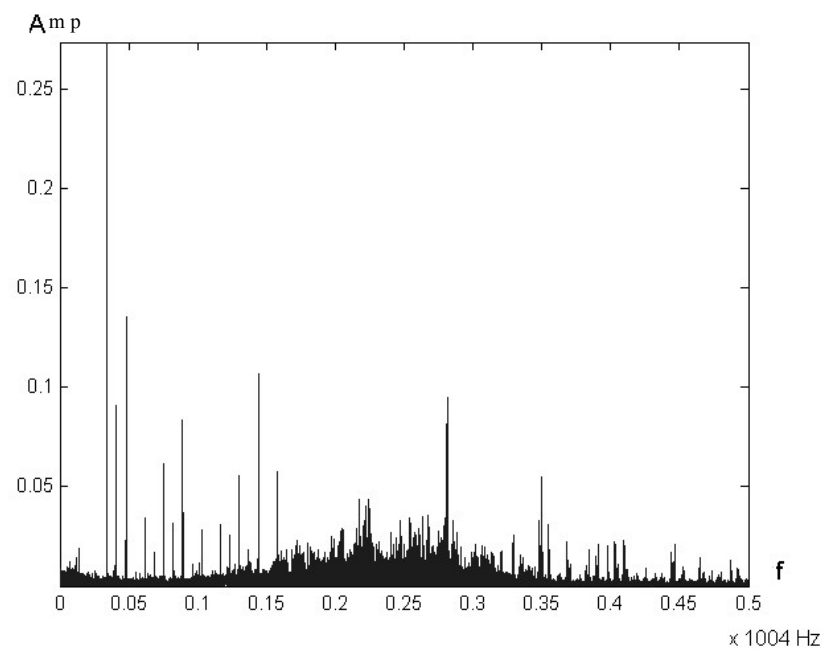

Rys. 9. Widma amplitudowe dla sygnałów pozyskanych: Aprzed remontem (pomiar 1, nastawa 15, punkt pomiarowy 6 , pion) i B- po remoncie (pomiar 1, nastawa 2, punkt pomiarowy 5 , poziom)

Widma sygnałów uzyskanych z silników przed i po remoncie różnią się w sposób zasadniczy. Rys. 9 pokazuje dwa przykładowe widma amplitudowe FFT dla odpowiednich sygnałów - jednostki na osi częstotliwości f są unormowane.

Analiza widma pokazuje, że dla wszystkich widm sygnałów uzyskanych przed remontem dominowała bardzo duża wartość składowej stałej (rys. 9A) - jest ona widoczna na rysunku jako prążek dla wartości 0 Hz. Dla sygnałów po remoncie składowa ta ulegała praktycznie eliminacji (rys. 9B). Wynik ten pokazuje, że klasyczne metody analizy widmowej mogą się okazać w dalszym ciagu decydujące w zakresie diagnostyki awaryjnej silnika.

Obliczono globalne parametry statystyczne takie jak średnia, mediana i odchylenie standardowe. Wyniki analizy tych parametrów są przedstawione $\mathrm{w}$ tabelach $6 \div 10$. Sa tam parametry obliczone dla wszystkich sygnałów, dla sygnałów zarejestrowanych w kierunku pionowym i poziomym poprzecznym oraz dla nastawy 2 i 15 (tabele $2 \div 5$ ).

Globalne parametry statystyczne dla wszystkich sygnalów uzyskanych dla lokomotywy ST44 - 2045

Tabela 6

\begin{tabular}{|l|c|c|c|}
\hline & Średnia & Mediana & $\begin{array}{c}\text { Odchylenie } \\
\text { standardowe }\end{array}$ \\
\hline Przed remontem & $0.265 \pm$ & $0.209 \pm$ & $1.857 \pm$ \\
& 0.075 & 0.069 & 0.651 \\
\hline Po remoncie & $0.036 \pm$ & $0.083 \pm$ & $7.939 \pm$ \\
& 0.091 & 0.259 & 5.786 \\
\hline $\begin{array}{l}\text { Różnica (po- } \\
\text { przed) }\end{array}$ & -0.229 & -0.126 & 6.082 \\
\hline
\end{tabular}


Globalne parametry statystyczne dla sygnałów zarejestrowanych w kierunku pionowym uzyskanych dla lokomotywy ST44-2045

Tabela 7

\begin{tabular}{|l|c|c|c|}
\hline & Średnia & Mediana & $\begin{array}{c}\text { Odchylenie } \\
\text { standardowe }\end{array}$ \\
\hline Przed remontem - & $0.306 \pm$ & $0.250 \pm$ & $1.757 \pm$ \\
pion & 0.079 & 0.076 & 0.636 \\
\hline Po remoncie - & $0.111 \pm$ & $0.290 \pm$ & $3.275 \pm$ \\
pion & 0.062 & 0.209 & 1.473 \\
\hline Różnica & -0.195 & 0.040 & 1.518 \\
(po - przed) & & & \\
\hline
\end{tabular}

Globalne parametry statystyczne dla sygnałów zarejestrowanych $w$ kierunku poziomym poprzecznym uzyskanych dla lokomotywy ST44 - 2045

Tabela 8

\begin{tabular}{|l|c|c|c|}
\hline & Średnia & Mediana & $\begin{array}{c}\text { Odchylenie } \\
\text { standar- } \\
\text { dowe }\end{array}$ \\
\hline Przed remontem & $0.225 \pm$ & $0.168 \pm$ & $1.957 \pm$ \\
- poziom & 0.039 & 0.015 & 0.649 \\
\hline Po remoncie - & $-0.039 \pm$ & $-0.125 \pm$ & $12.602 \pm$ \\
poziom & 0.036 & 0.063 & 4.613 \\
\hline Różnica & -0.264 & -0.293 & 10.645 \\
(po-przed) & & & \\
\hline
\end{tabular}

Globalne parametry statystyczne dla sygnałów zarejestrowanych dla nastawy 2 uzyskanych dla lokomotywy ST44 - 2045

Tabela 9

\begin{tabular}{|l|c|c|c|}
\hline & Średnia & Mediana & $\begin{array}{c}\text { Odchylenie } \\
\text { standardowe }\end{array}$ \\
\hline $\begin{array}{l}\text { Przed remontem - } \\
\text { nast. 2 }\end{array}$ & $\begin{array}{c}0.231 \pm \\
0.078\end{array}$ & $\begin{array}{c}0.223 \pm \\
0.092\end{array}$ & $\begin{array}{c}1.220 \pm \\
0.088\end{array}$ \\
\hline $\begin{array}{l}\text { Po remoncie - } \\
\text { nast. 2 }\end{array}$ & $0.030 \pm$ & $0.003 \pm$ & $4.896 \pm$ \\
\hline $\begin{array}{l}\text { Różnica } \\
\text { (po-przed) }\end{array}$ & -0.058 & 0.092 & 3.095 \\
\hline
\end{tabular}

Globalne parametry statystyczne dla sygnalów zarejestrowanych dla nastawy 15 uzyskanych dla lokomotywy ST44 - 2045

Tabela 10

\begin{tabular}{|l|c|c|c|}
\hline & Średnia & Mediana & $\begin{array}{c}\text { Odchylenie } \\
\text { standardo- } \\
\text { we }\end{array}$ \\
\hline Przed - nast. 15 & $0.300 \pm$ & $0.195 \pm$ & $2.494 \pm$ \\
& 0052 & 0.023 & 0.168 \\
\hline Po - nast. 15 & $0.042 \pm$ & 0.163 & $10.981 \pm$ \\
& 0.114 & \pm 0.335 & 6.234 \\
\hline $\begin{array}{l}\text { Różnica } \\
\text { (po- przed) }\end{array}$ & -0.258 & -0.032 & 8.487 \\
\hline
\end{tabular}

Podczas analizy nieliniowej do obliczeń czasu opóźnienia $\tau$ wykorzystano zarówno funkcję autokorelacji (jako opóźnienie $\tau$ bierze się pierwsze przejście przez zero) oraz uśrednioną informację wzajemną (jako opóźnienie $\tau$ bierze się pierwsze minimum lokalne). Większość obliczonych opóźnień czasowych $\tau$ przyjmuje wartość 1 , chociaż zdarzały się przypadki, gdy $\tau=2,3,4$. Wartość wymiaru przestrzeni fazowej została obliczona $\mathrm{z}$ wykorzystaniem zasady najbliższych fałszywych sąsiadów i oszacowana jako $d=9$. Wyniki analizy globalnego parametru nieliniowego maksymalnego wykładnika Lapunowa - są zaprezentowane w tabeli 11.

Wartości maksymalnych wykładników Lapunowa przed i po remoncie obliczone dla $\mathrm{d}=9$ sygnałów zarejestrowanych dla lokomotywy ST44 - 2045

Tabela 11

\begin{tabular}{|l|c|c|c|}
\hline & $\begin{array}{c}\text { Przed } \\
\text { remontem }\end{array}$ & $\begin{array}{c}\text { Po } \\
\text { remoncie }\end{array}$ & $\begin{array}{c}\text { Różnica } \\
\text { (po-przed) }\end{array}$ \\
\hline Wszystkie sygnały & $\begin{array}{c}0.334 \pm \\
0.237\end{array}$ & $\begin{array}{c}0.379 \pm \\
0.183\end{array}$ & 0.045 \\
\hline Sygnały zarejestro- & $0.310 \pm$ & $0.452 \pm$ & 0.142 \\
wane w kierunku & 0.270 & 0.236 & \\
pionowym & & & \\
\hline Sygnały zarejestro- & $0.358 \pm$ & $0.582 \pm$ & 0.224 \\
wane w kierunku & 0.195 & 0.476 & \\
poziomym & & & \\
\hline Sygnały zarejestro- & $0.513 \pm$ & $0.263 \pm$ & -0.250 \\
wane dla nastawy 2 & 0.219 & 0.047 & \\
\hline Sygnały zarejestro- & $0.155 \pm$ & $0.494 \pm$ & 0.339 \\
wane dla nastawy 15 & 0.014 & 0.195 & \\
\hline
\end{tabular}

W ramach analizy chwilowej wzięto pod uwage następujące parametry: prażki widmowe FFT 1, 2, 3, 4 i 5, średnią, momenty rzędu 2, 3, 4 i 5 oraz medianę. Jako szerokość okna przyjęto okres odpowiadający okresowi obrotowemu wału korbowego dla danej nastawy.

Analiza chwilowa dla każdego sygnału najpierw wyznaczyła odpowiednią przestrzeń parametrów, a następnie obliczała środek grupy punktów przestrzeni parametrów z wykorzystaniem techniki grupowania danych (algorytm grupowania po c średnich). Ostateczne rezultaty analizy chwilowej przedstawiono w tabeli 12. Duże wartości odchyleń standardowych wynikają ze znacznych różnic pomiędzy środkami w badanych grupach. Różnice te i odpowiednie odchylenia standardowe będą znacznie mniejsze, jeśli rozważyć osobno sygnały zarejestrowane w kierunku pionowym i poziomym poprzecznym albo dla odrębnych nastaw. Dla tych przypadków jednak zbyt mała liczność próby (zbyt mała ilość sygnałów wziętych do analizy) nie pozwala na wiarygodne stosowanie obliczeń statystycznych. Ponadto warto zwrócić uwagę, że część parametrów w tabeli może przyjmować wartości zarówno dodatnie jak i ujemne. 
Uśrednione położenia środków grup w przestrzeni parametrów dla sygnałów przed i po remoncie zarejestrowanych dla lokomotywy ST44 - 2045

Tabela 12

\begin{tabular}{|c|c|c|c|c|c|c|c|c|c|c|c|}
\hline & $\begin{array}{c}1 \\
\text { FFT } 1\end{array}$ & $\begin{array}{c}2 \\
\text { FFT } 2\end{array}$ & $\begin{array}{c}3 \\
\text { FFT } 3\end{array}$ & $\begin{array}{c}4 \\
\text { FFT } 4\end{array}$ & $\begin{array}{c}5 \\
\text { FFT } 5\end{array}$ & $\begin{array}{c}6 \\
\text { Średnia }\end{array}$ & $\begin{array}{c}7 \\
\text { Moment } \\
2\end{array}$ & $\begin{array}{c}8 \\
\text { Moment } \\
3\end{array}$ & $\begin{array}{c}9 \\
\text { Moment } 4\end{array}$ & $\begin{array}{c}10 \\
\text { Moment } 5\end{array}$ & $\begin{array}{c}11 \\
\text { Mediana }\end{array}$ \\
\hline Przed & $\begin{array}{c}16.935 \\
\pm \\
18.382 \\
\end{array}$ & $\begin{array}{c}997.864 \\
\pm \\
2600.468\end{array}$ & $\begin{array}{c}9.363 \\
\pm \\
4.748 \\
\end{array}$ & $\begin{array}{c}8.586 \\
\pm \\
6.011 \\
\end{array}$ & $\begin{array}{c}8.588 \\
\pm \\
4.338 \\
\end{array}$ & $\begin{array}{c}4.661 \\
\pm \\
3.590 \\
\end{array}$ & $\begin{array}{c}0.785 \\
\pm \\
0.625 \\
\end{array}$ & $\begin{array}{c}3.384 \\
\pm \\
2.942 \\
\end{array}$ & $\begin{array}{c}4.906 \\
\pm \\
3.415 \\
\end{array}$ & $\begin{array}{c}64.951 \\
\pm \\
62.526 \\
\end{array}$ & $\begin{array}{c}110.019 \\
\pm \\
130.854\end{array}$ \\
\hline Po & $\begin{array}{c}47.723 \\
\pm \\
37.066 \\
\end{array}$ & $\begin{array}{c}57.754 \\
\pm \\
52.375 \\
\end{array}$ & $\begin{array}{c}69.990 \\
\pm \\
38.228 \\
\end{array}$ & $\begin{array}{c}46.956 \\
\pm \\
36.960 \\
\end{array}$ & $\begin{array}{c}33.805 \\
\pm \\
28.274 \\
\end{array}$ & $\begin{array}{c}0.057 \pm \\
0.071\end{array}$ & $\begin{array}{c}96.062 \\
\pm \\
116.930 \\
\end{array}$ & $\begin{array}{c}11.666 \\
\pm \\
30.636\end{array}$ & $\begin{array}{c}71495.839 \\
\pm \\
113367.699 \\
\end{array}$ & $\begin{array}{l}6189.212 \pm \\
38696.018\end{array}$ & $\begin{array}{c}0.145 \\
\pm \\
0.209 \\
\end{array}$ \\
\hline $\begin{array}{c}\text { Różnica } \\
\text { (po- } \\
\text { przed) }\end{array}$ & 30.788 & -940.11 & 60,627 & 38.100 & 25.217 & -4.604 & 95.277 & 8.282 & 71940.933 & 6124.261 & -109.874 \\
\hline
\end{tabular}

\section{Wnioski końcowe}

Przeprowadzone badania pokazały możliwość wyraźnego odróżnienia stanu silnika przed remontem i po remoncie, co ma duże znaczenie diagnostyczne, gdyż pozwala wybrać te parametry diagnostyczne, przy pomocy których będzie można odróżnić zużyty (odpowiadający zagrożeniu awarią) stan silnika od stanu poprawnego.

Badania pokazały możliwość potraktowania stałej składowej (o zerowej częstotliwości) jako parametru określającego stan silnika lokomotywy spalinowej. Zwiększenie się tej składowej (szczególnie gdy stała składowa stanie się składową dominująca) wskazuje na zużycie silnika i stan bliski awarii.

Badania w zakresie globalnych parametrów statystycznych nie przyniosły zadawalających wyników, tym nie mniej, w większości przypadków wartości średnie i mediany są mniejsze dla sygnałów po remoncie, natomiast odchylenie standardowe jest zawsze większe dla sygnałów po remoncie.

Uzyskane wyniki wskazują również na możliwość zastosowania nieliniowych parametrów (maksymalnego wykładnika Lapunowa) do wykrywania i odróżniania stanu zużycia silnika lokomotywy spalinowej. Maksymalne wykładniki Lapunowa w większości przypadków maja wyższą wartość dla przypadku po remoncie, czyli dla silnika w lepszym stanie technicznym.

Metody analizy nieliniowej są nowym narzędziem przetwarzania sygnałów. Przedstawione wyniki wraz z innymi badaniami [3,5 i 9] wskazują na przydatność metody nieliniowej analizy sygnałów do diagnostyki silnika wysokoprężnego na bazie sygnału wibroakustycznego. Dalsze badania w tym zakresie dają w perspektywie możliwość zastosowania tych metod w przyszłych systemach diagnostyki pokładowej, zainstalowanych na lokomotywie spalinowej.

Uzyskane rezultaty wskazują również na przydatność chwilowej analizy sygnałów do diagnostyki silników wysokoprężnych na bazie sygnału wibroaku- stycznego. Analiza tych wyników pokazująca znaczące różnice pomiędzy środkami grup dla sygnałów przed i po remoncie, może się okazać istotnym kryterium dla odróżnienia stanów awaryjnych silnika. Biorąc pod uwagę wielką złożoność i różnorodność możliwych schematów pomiarowych należy jednak wyraźnie podkreślić, że dotychczasowe eksperymenty w zakresie widm chwilowych nie są ostateczne i wymagają dalszych badań [4,6,7 i 8]. Przyszłe eksperymenty w zakresie analizy chwilowej powinny wziąć pod uwagę większą ilość sygnałów, objąć większy zakres parametrów, uwzględnić większy zakres wymiarów rozważanej przestrzeni parametrów oraz zastosowanie bardziej nowoczesnych i efektywnych algorytmów grupowania danych, jak np. algorytm rozmyty lub posybilistyczny.

Zaproponowane metody analizy sygnałów nadaja się do przyszłego zastosowania $\mathrm{w}$ systemach diagnostyki pokładowej zainstalowanych na lokomotywie spalinowej. Prowadzą one do stosunkowo prostych metod obliczeniowych, łatwych do zaimplementowania na dowolnym komputerze, a w tym również na procesorze sygnałowym.

\section{Literatura}

[1] H. D. L. Abarbanel: Analysis of Observed Chaotic Data, Springer, 1996.

[2] J. C. Bezdek: Pattern Recognition with Fuzzy Objective Function Algorithms, Plenum Press, 1987, second edition.

[3] P. Boguś, J. Merkisz, R. Grzeszczyk, S. Mazurek: Nonlinear Analysis of Combustion Engine Vibroacoustic Signals for Misfire Detection. SAE Technical Paper Series 2003-010354.

[4] P. Boguś, K. Lewandowska: Short-Time Signal Analysis Using Pattern Recognition Methods. Lecture Notes in Artificial Intelligence: Artificial Intelligence and Soft Computing, 3070, 2004. 
[5] P. Boguś, J. Merkisz: Diagnostyka pokładowa silników wysokoprężnych z wykorzystaniem nieliniowych metod analizy sygnatów. Pojazdy Szynowe, 1/2004.

[6] P. Boguś, R. Grzeszczyk, J. Merkisz: Diagnostyka pokładowa silników wysokoprężnych z wykorzystaniem chwilowej analizy sygnatów. Pojazdy Szynowe, 1/2004.

[7] P. Boguś, J. Merkisz: Wykrywanie zjawiska wypadania zaptonu $w$ silniku o zapłonie samoczynnym $w$ oparciu o grupowanie danych $w$ krótkoczasowej analizie sygnatów wibroakustycznych. Silniki Spalinowe, 4, 2005.

[8] P. Boguś, J. Merkisz: Short Time Analysis of Combustion Engine Vibroacoustic Signals with Using Pattern Recognition Techniques. SAE Technical Paper Series 2005-01-2529.

[9] P. Boguś, J. Merkisz: Misfire Detection of Locomotive Diesel Engine by Nonlinear Anlaysis. Mechanical Systems and Signal Processing, 19, 2005.

[10] C. S. Daw, M. B. Kennel, C. E. A. Finney, F. T. Connolly: Observing and Modeling Nonlinear dynamics in an Internal Combustion Engine. Physical Review E, 57, 1998.
[11] Decyzja NR 36/2000 Naczelnego Dyrektora Kolejowych Przewozów Towarowych CARGO z dnia 5 czerwca 2000 r. w sprawie utrzymania technicznego pojazdów trakcyjnych.

[12] R. Duda, P. Hart: Pattern Classification and Scene Analysis, New York, Wiley Interscience 1973.

[13] A. P. Foakes, D. G. Pollard: Investigation of a Chaotic Mechanism for Cycle-to-cycle Variations. Combustion Science and Technology, 90, 1993.

[14] J. Jerrelind, A. Stensson: Nonlinear Dynamics of Parts in Engineering Systems. Chaos, Solitons and Fractals, 11, 2000.

[15] T. Kucharski: System pomiaru drgań mechanicznych, Warszawa, WNT 2002.

[16] Materiaty internetowe.

[17] S. K. Mitra, J. R. Kaiser: Handbook for Digital Signal Processing, Wiley 1993.

[18] J. Szabutin: Podstawy teorii sygnatów, Warszawa, WKiE 2003.

[19] W. Wang, J. Chen, X. K. Wu, Z. T. Wu: The Application of Some Non-linear Methods in Rotating Machinery Fault Diagnosis, Mechanical Systems and Signal Processing, 15, 2001. 